foreign policy in the succeeding crises is not given. Although the author describes Haymerle as a "quiet and painstaking figure" (p. 105), the attempt is made to emphasize the Austrian minister's real achievements while in office.

The book is based almost exclusively on material in the Haus-, Hof- und Staatsarchiv, with less attention given to the literature on the subject. This condition is particularly apparent in the sections dealing with the Eastern Question, a problem which dominated Haymerle's career. In the bibliography the author has not included even such an obvious reference as M. A. Anderson, The Eastern Question. This deficiency has led to major and minor errors in questions of fact and interpretation. For instance, the Bulgarian exarchate controversy of the 1870 s did not involve the "union of the Russian and Bulgarian churches" (p. 46); the issue in the Straits question during the discussions over the Three Emperors' Alliance concerned not "closure" but the multilateral nature of the agreements relating thereto. It is also difficult to accept the statement that Austrian policy after 1878 was "more enlightened . . . making Austria-Hungary's weight felt ... but in a more subtle way" (p. 170).

Nevertheless, this book does give a balanced description of the career and character of an important Austrian diplomat whose reputation has certainly suffered in contrast to that of his undoubtedly stronger and more colorful contemporaries, Andrássy and Bismarck.

Barbara Jelavich Indiana University

\title{
EGYHÁZI TÁRSADALOM A KÖZEPKORI MAGYARORSZÅGON. By Elemér Mályusz. Budapest: Akadémiai Kiadó, 1971. 398 pp. 78 Ft.
}

This book without doubt marks a high point in the scholarly work of the worldrenowned Hungarian historian, even though the original idea was formulated as early as the end of the 1940s in his university lectures (so we are told, at least, in the foreword). To characterize Mályusz's wide-ranging oeuvre here would take us far afield. Let us mention only that he has discussed the most varied periods of Hungarian history, always with the rest of Europe in mind, and has never wished to be identified exclusively as a medievalist. A glance at the outstanding work of the author's youth on the Palatine Alexander Leopold (Sándor Lipót föherceg nádor iratai, 1790-1795, Budapest, 1926) will clarify this.

The typical method employed in this book is as follows. The author does not confine himself-unlike many medievalists-to an exact exposition based on source criticism, but always seeks to place progressive sociocultural and socioeconomic aspects in the foreground of his investigation. This is evident in the chapter topics: the beginnings of Christianity in Hungary, the secular clergy (with a detailed classification), monachism, and the literature of the times, followed by an epilogue on the emergence of a secular educated class. Mályusz in developing his themes and theses is far from limiting himself to the narrow circle of Hungarian historiography, but places each question he seeks to answer in the broader European context- to say nothing of his great erudition in non-Hungarian sources and scholarly studies. It is thus regrettable that this work could not be published simultaneously in another language, such as English, German, or French. A fully detailed review would therefore be justified only if the book could be used by those who do not know Hungarian. 
Especially informative is the chapter on the secular clergy. Besides the intellectual and religious culture, the material foundations of this class are given full attention. Here also may be found an attempt to study the individual Hungarian dioceses (especially in the waning Middle Ages) statistically-the income of the dioceses, the cathedral chapters, the bishops, and the social origin of the high clergy. The author also deals at length with the "secularization" of the church in the late fifteenth and early sixteenth century, which seems comparable to Delumeau's concept of "dechristianization." Regarding the clergy the author also examines the steadily increasing amount of writing (including that of the so-called laity)whereby he seeks to fathom the so-called infrastructure of the medieval orbis christianus. And to elucidate precisely this infrastructure, also during earlier centuries, is an important desideratum of medieval church history. If traditional sources are lacking, should not one have recourse to other evidence (for example, that of the fine arts)?

The book is an outstanding synthesis of the intellectual, cultural, and spiritual aspects of the last centuries of the Middle Ages, dealing with Hungary in the narrow sense but always bearing in mind the general European situation. No historian who is concerned with the church history of the time can afford to ignore this work by Mályusz, even though the book is at present accessible only to those who know Hungarian.

MORITZ CSÁKY

Vienna

A NEMZETI PARASZTPĀRT TöRTENETE, 1944-1948. By István Tóth. Budapest: Kossuth Könyvkiadó, 1972. 326 pp. $23 \mathrm{Ft}$.

In this book István Tóth traces the brief history of the National Peasant Party (NPP) of Hungary during the crucial postwar period, when electoral competition prevailed. The book contains numerous carefully documented facts (from sources that are not available to Western scholars).

The Peasant Party never captured the imagination of the Hungarian electorate. In 1945 they polled 6.87 percent of the ballots (p. 110); and in 1948, even after the Smallholders Party was in complete disarray, the NPP captured only 8.3 percent of the votes (p. 239). The detailed analyses of these elections are the most rewarding parts of the book. Tóth meticulously presents the election results county by county, and occasionally on the district and even the precinct level. The results on the local levels are compared with the showing of the other parties.

The poor election results in both 1945 and 1948 were followed by upheavals within the NPP leadership. Tóth discusses these and other leadership crises and concludes that the divisiveness within the party and the lack of "democratic centralism" were responsible for the NPP's misfortunes. It becomes obvious that the Communists both from within and from without prevented the NPP from following independent and pro-peasant policies and joining forces with the moderate Smallholders in opposition to the two workers' parties. However, in spite of its many pro-Communist leaders, the NPP at times managed to assert itself and play a constructive role in Hungarian politics. Credit is due essentially to Imre Kovács, general secretary of the NPP, to his supporters, and to the small group of "thirdroaders" (those intellectuals who believed in a future for Hungary with a flourishing agriculture not connected with communism or capitalism) who incessantly 